\title{
THE GUISE OF U.S. NATIONAL REFERRAL AUTHORITY TO "OTHERING" REFUGEES AND ASYLUM SEEKERS: A TWAIL APPROACH
}

\author{
Alifa Salsabila \\ e-mail: alifafauziar@mail.ugm.ac.id
}

\begin{abstract}
President Trump's issuance of Executive Order 13769 titled "Protecting the Nation from Foreign Terrorist Entry into the United States" restricts and even bans access to refugees and asylum seekers from seeking international protection in and from the United States. It is done by creating narratives that refugees and asylum seekers are capable of committing "potential threats" under the umbrella of terrorism. This study aims to dismantle the paradoxes the Executive Order conveys. It focuses on the international refugee regime under the ambit of international law and a broader context of immigration debatessocially, economically, and culturally. This study uses the Third World Approach to International Law (TWAIL), making it possible for academic legal discussion to correspond in cultural context. The findings show that Trump's Executive Order 13769 functions as the tool for the United States to "othering" refugees and asylum seekers as foreign terrorists in order to wage its national interests while ruling out humanity and the regime.
\end{abstract}

Keywords: asylum seekers; Donald Trump; foreign policy; refugees; terrorism

DOI $\quad:$ https://doi.org/10.22146/rubikon.v7i2.62747

Available at https://jurnal.ugm.ac.id/rubikon/article/view/62747

This work is licensed under a Creative Commons Attribution-ShareAlike 4.0 International License

\section{INTRODUCTION}

In September 2020, President Donald J. Trump spoke for the United Nations General Assembly and let the guests and audiences knew that in order to function best as an (international) organization, the United Nations must focus to tackle down the 'real' problems of the world. The 'real' problems, he briefly addressed, included persecutions such
Article information

Received: 16 August, 2020

Revised: 30 August, 2020

Accepted: 13 September, 2020 as religious persecution and ethnic cleansing of religious minorities. The speech has, then, gone controversial. Trump perhaps, as the Mister President of the United States and an identified 'American' himself, forgot to look at his own backyard before delivering the speech. In other words, Trump might have forgotten the 'real' problems he, arguably, has been 'creating' in his home country-under his administration - which has become the 
huge concern of humanity. That is Trump's Executive Order 13769 titled "Protecting the Nation from Foreign Terrorist Entry into the United States" that restricts visas issuance and bans permission of travels from seven Moslem-majority countries, including suspending the United States Refugees Admissions Program (USRAP). In the Executive Order, Trump is clearly assuming people (including but not limited to) such as refugees and asylum seekers as foreign terrorists capable of committing "potential threats" to harm the American nation and citizens. In antithesis to its own history of immigration as part of the establishment of the American nation whose in it lies the very dear memory of refugees and asylum seekers seeking protection in a 'foreign land' while being persecuted under colonial rule, Trump's administration chooses to deny entry for refugees and asylum seekers and even has deported 30.000 of them throughout the COVID-19 outbreak (Williams, 2020).

As part of the American history, the fact that the United States was partially built upon the notions of individual freedom as well as state protection for people to be free from persecutions (Library of Congress, n.d.), especially religious persecutions, are undeniable. It requires the rule of law to put such of these spirits live into action. But Trump's perceptiveness on refugees and asylum seekers as foreign terrorist - capable of committing what he fears of potential threats - affects his legal behaviour to create such a policy. Trump performs the signs of fear-economically, politically, and culturally - over refugees and asylum seekers that, he believes, will likely to strike down the American civilization in general or the established social structure of the American white, Anglo-Saxon, protestant citizens in particular. The policy positions refugees and asylum seekers as "potential threats". It means that there is a sense of something that Trump, as a President, must prevent, anticipate, and even overcome before it gets the nation, of which he is responsible of protecting, devastated by what 'foreign terrorists' are capable to commit. The word "threat" is repeatedly found throughout the text of the Executive Order. This article refers to the "threat" as "potential threats," since there is no official statement on what kind of threat, or public evident-based of threat, that explains the "threat" Mister President tries to articulate.

Trump exercises his executive power as if he is not aware that the United States is a state party to the 1951 Refugees Convention and its 1967 Protocol, created upon the urgency of human rights issues for refugees and asylum seekers, and has established international system of "international protection" to refugees and asylum seekers. The United States, in the manner of its legal commitment, shall respect and 'obey' the law as part of the responsibility in coalescing in the international community. In 2020 alone, the enforcement of the Executive Order has cut $84 \%$ of refugees and asylum seekers quota compared to President Obama's final year of administration. From asylum to deportation issues, restricting visas to banning enters from some countries, and cutting quotas of refugees and asylum seekers provided by the United States, Trump's administration, arguably, has taken the United States immigration policies to rather "anti-immigration" (Glennon, 2020). Trump's administration claims that it most 'saves' the United States and American citizens from falling into unwanted labour forces, security issues, and unfavoured economic growth rate, which, instead, is likely 
to affect the future of the country itself (Anderson, 2020).

Under the ambit of international law, banning people from seeking protection caused by persecutions in their home country - as what does happen in the refugees and asylum seekers context - means violation to commitment on human rights in respect of international protection and the principle of "non refoulment." The 1951 Refugees Convention and its 1967 Protocol forbid state parties to the Convention to ban, block, reject, let alone forcedly deport refugees and asylum seekers to their home country where their lives are put at stake. Customary and normatively, the United States, is legally bound to the substantives of the Convention. But neither of the commitments, normatively nor customary, is performed properly_not because the United is unable to do so but because Trump administration is rather unwilling to do it. And this legal proposition is what the article will be dismantling using the Third World Approach to International Law (TWAIL) in respect to the United States so-called "commitment on human rights" at the global level, as part of the international community.

\section{DISCUSSION}

TWAIL is best understood as an approach as a journal suggested (Singh, 2019, p. 1):

It is an approach drawn from the history of the encounter between international law and colonization. As a distinctive way of thinking about international law, TWAIL is a historically aware approach that, through academic scholarship and discussion, makes innocent third worlds aware of an openly colonizing and dominating first world and works towards eliminating the disadvantages of an underdeveloped in the Third World.
It offers a critical view where people could use international law as an eye-opening tool rather than, 'a supplier of biased dreams' in seeing international politics between the divided world consists of the first world countries and the third world countries, the developed ones and the developing - and even the underdeveloped - ones, or the Western and the non-Western. One might guess that the 'dreams' as such as of the concept or parameters the Western-based civilization creates, refer to the standards of the so-called 'development' and 'human rights' which favor the Westerners more than anyone else in the rest of the world. In the realm of the divided world, international politics favor international law to be predominately dominated by the great powers conveyed by the Western, capitalist, developed, first world countries such as France, England, and the United States. The history of these countries is wellknown as the colonizers, especially the United States case perceived as countries that still manage to project the legacy on the counter of the colonial power in any social, cultural, economic, or political dimensions throughout the world that benefit their existence. To narrow down the case, Trump's foreign policy 13769 falls under the ambit of international law which closely works with the legal framework of the refugee regime.

\section{Approaching the Nature of Refugees, Asylum Seekers, Foreign Terrorist, and Potential Threats by Normative Definition}

We start by discerning the big key terms in this article which are "refugees," "asylum seekers," "foreign terrorists," and "potential threats." According to international legal regime that already exists for quite some time, which most of the terms here are very wellunderstood concepts generated from 
Customary International Law (CIL) that has been acknowledged practiced by the Western civilization:

1. "Refugees," defined by UNHCR in its official website (UNHCR, n.d.), are understood as "people who have fled war, violence, conflict, or persecution and have crossed international border to find safety in another country" in order to simplify the definition of refugees from the 1951 Refugee Convention (UNHCR) that defines refugees as "someone who is unable or unwilling to return to their country of origin owing to a well-founded fear of being persecuted for reasons of race, religion, nationality, membership of a particular social group, or political opinion."It is well understood that, "to employ the term 'refugee' is both todescribe it and ascribe a value to it" (Haddad, 2008, p. 25). Consequently, the acknowledgment to refugees is not merely political. It is not an acknowledgement of labels done by "free" labelling of who is labeling whom, based on what, and to achieve what; but a form of acknowledgment that demands a distinct legal recognition in which some people do perform "exceptional circumstances" where their life is threatened due to particular reasons. The concept is thus descriptive and normative.

2. "Asylum seekers," according to USA for UNHCR, are understood as people who "flee their own country and seek sanctuary in another country, they apply for asylum - the right to be recognized as a refugee and receive legal protection and material assistance" (USA for UNHCR, n.d.). And adding the emphasis, it further stated that, "An asylum seeker must demonstrate that his or her fear of persecution in his or her home country is well-founded" (USA for UNHCR, n.d.). Amnesty International further explains (Amnesty International, 2019), "in countries with individualized procedures, an asylum seeker is someone whose claim has not yet been finally decided on by the country in which he or she has submitted it. Not every asylum seeker will ultimately be recognized as a refugee, but every refugee is initially an asylum seeker." What needs to be highlighted here is that there are two procedures in recognizing asylum seekers and refugees. First, is done by international organization that is responsible for doing the job, which is UNHCR. And, second is by individual countries who are state parties to the 1951 Refugee Convention and its 1967 Protocol, and thus has its own procedures in doing the job - which the United States, in this case, is one example of countries having its own procedures in acknowledging asylum seekers and recognizing refugees.

3. "Foreign terrorist," understood as subject labelled as "foreign terrorist fighters" (FTFs), are "individuals who travel to a State other than their State of residence or nationality for the purpose of the perpetration, planning or preparation of, or participation in, terrorist acts or the providing or receiving of terrorist training, including in connection with armed conflict" (United Nations, n.d.). FTFs, consequently understood, are capable of committing terrorism, international and domestic. International terrorism is "Violent, criminal acts committed by individuals and/or groups who are inspired by, or associated with, designated 
foreign terrorist organizations or nations (state-sponsored)" while domestic terrorism is "Violent, criminal acts committed by individuals and/or groups to further ideological goals stemming from domestic influences, such as those of a political, religious, social, racial, or environmental nature" (FBI, n.d.).

4. "Potential threats"-with no clear definitive reference-only hover around the sense of fear of (indescribable) attacks that must be prevented, anticipated, and even overcome, before any serious one, such as in refer to the $9 / 11$ tragedy, happens (again). But at the very least, in light of the "potential threats," we could know that the threat "ranges from the possibility that they will get involved in terrorist acts outside of their home country, to the threat that, once they return to their home countries, they will utilize their knowledge and experience of handling weapons and explosives in order to plan and carry out terrorist acts, set up new terrorist cells, recruit new members, or provide funds or training for future terrorist acts" (UNODC, p. 4). And the challenge to tackle down the FTFs, other than internationally acknowledged, falls as a right to full self-referral authority of every country to identify so. This right, known as the right of "self-defense," possessed by individual countries, is generated from the United Nations Security Council (UNSC) Resolutions 2170 (2014) and 2178 (2014) whose foundation is derived from the Chapter VII of the UN Charter that rules about "international threat to peace and security", in which FTFs are considered to bring threat to international peace and security. Hence, "the resolutions oblige states to take wide-reaching measures to prevent and suppress this flow" (ODIHR, p. 6).

The nature of each concept performs a clear 'nature gap' between refugees and asylum seekers and how the international community, then, must treat them, compared to who foreign terrorists are and how the international community must quell them. The concepts of refugees and asylum seekers are derived from the urgency to treat well humanity regardless of the man-made reasons - which are persecutions - blocking its way. International legal regime on refugees, asylum seekers, and human rights articulate the distinct system to treat these people the way they deserve and must be acknowledged as humans merely because they are humans. Meanwhile, the concepts of foreign terrorists and potential threats depart from the sense of fear. And this fear generates responsibility to envision the future where acts of terrorismi.e., the "potential threats"-is in best form to prevent such attacks and cause such devastation. Or, is it another form of "potential threats" that Trump is trying to convey?

As the result of Trump administration's issuance and enforcement of the Executive Order 13769, which has become the primary source that provides shades in Trump's continuous anti-immigration policies, more policies restricting and banning access for refugees and asylum seekers to seek for international protection from the United States government continued to follow. In 2018, Trump enacted another "asylum ban" that strongly restricted immigrants coming to the American soil who sought for asylum, despite of, once again, failing international law to be committed to its own human rights commitment at the global stage followed by a 
"nationwide block" in 2019 claiming to protect the United States borders from refugees and asylum seekers seeking sanctuary in the American soil, reinstated by the federal court (Ibe, 2020). Immigration in the United States has been polarized to degrees where immigration has no longer been an issue to law and politics (including economic), but rather culture. At the very least, the last thirty-five years has been a significant period where income inequality plays a very important role in shaping anti-immigration narratives. Since 1970s, the income gap in the American society, between the low-class and high-class society, has gone beyond just financial matter than in anywhere else across the globe $(\mathrm{Xu}$, Garand, \& Zhu, 2016). Escalating from just financial and economic, the income gap leads to political consequences in state and federal levels where policy of immigration is being made from, including giving rooms for cultural debates to grow in between. Even though economists have been debating on the effect that immigration has caused to the country, which some suggest that immigration is beneficial to the economic welfare and others suggest that it only has a little impact that is insignificant to the economic growth of the country, they might have something more than just profit and loss analysis of immigration policy which is how the existing income equality itself politically influences the nation's policy toward its immigration attitudes. Therefore, it is understood that "based on a complex intersection of economic interests, foreign policies, racial and ethnic biases, and other factors, immigration laws are the gates that allow some immigrants into the country while shutting others out" (Ueda, 2006, p. 6).

\section{TWAIL Challenges: The Paradoxes}

There are at least two paradoxes in this case. First, when it comes to the image of the United States that we are familiar with international campaigns and commitment on upholding human rights, Trump's perceptiveness on refugees and asylum seekers as foreign terrorists capable of committing potential threats is backlashing the United States stance as a state party to the 1951 Refugees Convention and its 1967 Protocol, normatively and politically. As we have discussed the nature of refugees, asylum seekers, foreign terrorists and potential threats, we have understood its distinct difference that Trump is trying to intertwine. Unless, he is trying to convey other forms of "potential threats" that could actually fall under the bigger umbrella, which is under the ambit of more political, social, cultural issues. But when we try to read the "potential threats" here as an act of terrorism as is stated in the Executive Order 13769 that:

Section 1. Policy and Purpose. (a) It is the policy of the United States to protect its citizens from terrorist attacks, including those committed by foreign nationals. The screening and vetting protocols and procedures associated with the visaissuance process and the United States Refugee Admissions Program (USRAP) play a crucial role in detecting foreign nationals who may commit, aid, or support acts of terrorism and in preventing those individuals from entering the United States. It is therefore the policy of the United States to improve the screening and vetting protocols and procedures associated with the visa-issuance process and the USRAP (National Security \& Defense, 2017).

The Executive Order further rules to suspend the USRAP if any indication of threat is found by the government and "grant case-by-case 
waivers when they determined that it was in the national interest to do so". It is written in Section 1(b) (ii), in which "they" refers to the Secretary of State and the Secretary of Homeland Security. Furthermore, it clearly states list of countries whose "nationals continue to present the heightened risks to the security of the United States" as written in Section 1(e) (National Security \& Defense, 2017): Iraq, Syria, Iran, Libya, Somalia, Sudan, and Yemen.

In the first paradox, Trump creates a narrative where the USRAP, as the United States procedure and mechanism of screening asylum seekers and granting the status of refugees, is among other ways that could lead "foreign terrorists" enter the United States. By suspending the USRAP altogether and naming the list of countries he believes is presenting threats to the security of the United States, he generalizes the applicants - the people who, under the international legal regime, are trying to get international protection from and in the United States - as foreign terrorists capable of committing "potential threats." The generalization that Trump is making through the Executive Order 13769 is crucial and can be fatal. It is crucial since the standard or parameter of potential threats to national security falls entirely in the hands of the national referral authority. It is, then, on the hands of the authority to justify a case relies, whether to accept or to reject one. And it is fatal because it can lead to a biased narrative.

The national referral authority, which could be perceived as the country's exercise of sovereignty, is confidential and this means the generalized narrative based on confidential investigation should be put into a question to the system rather than a ban or block of an entire entry of a country and falsely claim that its country nationals are all, for example, involved in the act of terrorism. This part in this proposition favors human rights for refugees and asylum seekers by intertwining them with foreign terrorists capable of committing potential threats. Notwithstanding, international politics of the United States on the global stage keeps campaigning to uphold human rights. Even though the issue of human rights is not assessed from an ethical point of view, it is rather clearly seen from the perspective of legal positivism. The United States model of modern legal positivism is the later element that needs to be questioned. H.L.A. Hart, as one of the distinguished positivists "agree that the law can be entirely based on social sources but also believe that this does not have to be the case. Instead, when law refers to moral standards, these standards become incorporated into the law" (Janmyr, 2013, p. 31). However, there are no part on the proposition dedicated to the acknowledged law-international law on refugees and asylum seekers-let alone the moral standards. It creates confusion about the kind of legal positivism being performed by the United States under Trump's Executive Order 13769.

The second paradox comes with a distinct logic that falls under two circumstances that all, at the end of the day, favor the position of the United States. Firstly, the Executive Order's rule on suspending the USRAP — after offering all the justifications it tries to make as conveyed in the first paradox - tries to clarify that the policy, representing the stance of the United States, is not trying to discriminate any particular religion. Instead, it tries tomake an effective attempt to tackle down foreign terrorists trying to enter the United States through the USRAP. To sustain the "human rights issues," it further explains that, "any 
foreign national who has been granted asylum; any refugee who has already been admitted to the United States; or any individual who has been granted withholding of removal, advance parole, or protection under the Convention Against Torture." Secondly, adding another emphasis on the United States' exercise of national referral authority, the Executive Order states that itdoes "grant case-by-case waivers when they determined that it was in the national interest to do so". The word "they" refers to the Secretary of State and the Secretary of Homeland Security (National Security \& Defense, 2017).

The two circumstances prevail to design a situation where it is best possible for the United States to not be "wrongly-accused" of violating basic norms of international law regarding refugees and asylum seekers, rather, performing of itself being highly alert on "potential threats" while making itself favorable to do things based on national interests. Here are how the two circumstances works with the second paradox, the flawed logic in the Executive Order:

- First, when Trump's Executive Order 13769 decides to ban entries from a list of seven Moslem-majority countries and further in the statement make clear of himself that the United States is not trying to discriminate any particular religion rather to carefully re-screen the entries from the seven countries, the Executive Order becomes peculiar. It becomes peculiar as the Executive Order states that, "the risk of erroneously permitting entry of a national of one of these countries who intends to commit terrorist acts or otherwise harm the national security of the United States is unacceptably high" (National Security \& Defense, 2017) followed by a special case of Iraq which by the United States investigation is becoming an active combat zone making the Iraqi government incapable to "identify fraudulent travel" as written in the Section 1(f) and (g). The peculiarity lies exactly at the incompetency that the United States system of travel and admission that, at the end of the day, permits such entries. If later, in the future, the United States begins to learn that there are some foreign terrorists who manage to get in the United States - in refugees and asylum seekers context - through the USRAP, then the flaw is in the USRAP system itself. Why bother to blame the incapability to the Iraqi government, let alone generalize all the Iraqi people who seek for international protection, when the United States does perform some incompetence in the system too? An article writes that Trump's antiimmigration policy has been diverging previous administrations in tackling down terrorism by blurring it in the bigger context of contestation. The article of interview with Peter Neumann, a professor at Security Studies at King College's London, says, "Trump is the first president of the post-9/11 era to so firmly link terrorism to immigration". It further states "the single most important difference between Trump and his predecessors - the extent to which he conflates Islam, immigration, and terrorism" (Gilsinan, 2018). Trump keeps on linking terrorists with immigrants and Moslems, blurring the lines between them as if the generalization narrative he creates is the most accurate version of all. "His rhetoric diverges from that of previous post-9/11 administrations, which took care 
to not implicate all Muslims or all immigrants" (Gilsinan, 2018). However, to justify its meaning, it needs to be seen that it still is a country that supports human rights of the refugees and asylum seekers. This adds more condition that it does not remove people with special circumstances as in written in the Section 3-which includes those who have been granted refugee status and given asylum.

- Second, even though the phrase "would be in the national interest to do so" seems to just pass through sections in the Executive Order 13769 , it is really a highlight for TWAIL to discuss. For this, let me borrow Antony Anghie's introduction on the war on terrorism:

Imperialism has once again become the focus of analysis in international relations, initially, as a consequence of the victorious emergence of the United States as the single global superpower intent on exercising its unprecedented influence to ensure its own security and further its own interests and, following 9/11, the commencement of a 'war against terrorism' (WAT) animated by principles and policies that, when taken together, closely resemble, if not reproduce, imperialism (Anghie, 2004, p. 273).

Anghie provides a postcolonial point of view in seeing how the United Statesalong with the war on terror (WAT) generated by the $9 / 11$ tragedy — is able to manage its imperialism by imposing their national interests on the field, from security issues to social, economic, and cultural issues. There are political and legal considerations underlying the use of word "war" in the narrative, especially as to characterize terrorism more as "armed attacks" that must be massively overcome by war against it and thus the war to it is justified to take place than just crimes. Anghie further suggests that the WAT uses the pre-emptive self-defense concept as what might be described the "Bushdoctrine". As the most justifiable way of response to terrorism, it carries the narrative in the modern realities that all nations, with the ample support of the American government, must all fight against terrorism (Anghie, 2004). The concept is also well acknowledged in Article 51, Chapter VII of the United Nations (UN) Charter. Article 51 of the UN Charter states:

Nothing in the present Charter shall impair the inherent right of individual or collective self-defence if an armed attack occurs against a Member of the United Nations, until the Security Council has taken measures necessary to maintain international peace and security. Measures taken by Members in the exercise of this right of selfdefence shall be immediately reported to the Security Council and shall not in any way affect the authority and responsibility of the Security Council under the present Charter to take at any time such action as it deems necessary in order to maintain or restore international peace and security (United Nations, n.d.).

President Bush was able to use this concept and expand it to his version of war-what to do about terrorism and how to fight it- to convince international community that WAT, the way America does it, is permitted under international law. The divided stance of the world has always been clear since Bush stated that, "Every nation, in every region, now has a decision to make. Either you are with us, or you are with the terrorists" (The Washington Post, 2001). The war does not 
have to deal with those who are, seen at case by case level, running away from it to save their lives. The war does not have to bother the fact that some who flee terrorism might be the victims of it. The war does not have to "provide" mercy for those who might have (ever) been involved then seek asylum from it. The distinctions are crystal clear, the world only consists of those who are terroristsin whatever involvement it is - and those who are not-which is those who fight against it. Moreover, this legacy of such making distinctions, explained in postcolonial view, is coming from what remains of the imperial culture.

In short, the first world countries, specifically the United States, can project and impose their power, soft and hard, politically and legally, to justify whatever favors them the most. Whether it is the campaign of human rights they like to do at the global stagewhich is commonly done by making accusations of violations of human rights in other countries, added with a little bit of spice of lack of democracy in the narrative - or the all-justified means they use in fighting against terrorism on the WAT-anything from causing civilian casualties, destruction of environment, or in this context is outlawing humanity in the practices of law regarding of refugees and asylum seekers with its very different nature from FTFs - the United States is able to perform and impose their national interests. Borrowing a metaphor from Makau Mutua, the "Savages-Victims-Savior" (SVS), that explains the three dimensions in the human rights discourse and narratives that always spin around the non-Western stateswhich refer to the third world countries whose lack of democracy is so visible from the Western, democratic eyes - as the savages that always violate human rights, the victims whose human rights have been taken away by the savages, and the saviors, the light to all and every problem which is the Western, democratic countries-whose societies and government respect and uphold human rights (Mutua, 2001); the United States in its paradox is the savior, the sanctuary, and the perfect model for the compliance and fulfillment of human rights issues while making itself clear, asserting that they have never been the savages in the narrative that violate the law, rather, again, always be the savior in other issues too, such as terrorism, even though flaws and contradictions are found in their footprints. At the end of the day, it is just everything that the United States is based on their national interests. And to wage their national interest, they do justifications and narratives that favor their stance and position so they are never to be accused of doing mistakes, let alone committing something wrong.

\section{CONCLUSION}

Whenever placed in a 'new' or 'foreign' land as part of their journey in pursuing life without persecution, refugees and asylum seekers often live with discrimination, especially experiencing both overt and covert forms of racism. They are being labeled for their identities and associations - including but not limited to-race, religion, and origins of countries. Refugees and asylum seekers experience unequal access to human rights such as asylum and protection to be free from persecution. It all undermines the fundamental assertion that human rights are universal and apply equally to everyone, as it is conveyed, even in the American Constitution. From the attitude towards refugees and asylum seekers, there are exceptional circumstances in the name of humanity of which people, carrying 
these labels must urgently be protected under the law that transcends politics, economic, even other cultural issues. If, what President Trump is believing that immigration, including that comes from refugees and asylum seekers, does contribute to income inequality which makes the federal government takes side on the anti-immigration policy, why then many researches prove that immigration has always had and will always have been substantial to the country's economic growth.

The threats, then, seem to go beyond financial matters. What Trump makes are mere assumptions, and he is, under the country's guise of "self-defence" or best termed as the "Bush doctrine" in the WAT chooses to rule out humanity by imposing narratives that refugees and asylum seekers are foreign terrorists who are capable of committing potential threats. It can be concluded that it is not the law that is being upheld in the status quo, but rather such self-referral and selfjustification of law that give foundation underlying Trump's anti-immigration policy to othering refugees and asylum seekers as foreign terrorists who are capable of committing potential threats to the American nation and American citizens by creating narratives - as urgent as possible-in "othering" refugees and asylum seekers. Trump, then, through the enforcement of the Executive Order 13769 exercises his power to protect his nation, without bothering the paradoxes - the flaws - he creates in the United States stance and position as part of the international community.

\section{REFERENCES}

Amnesty International. (2019, January 24). What's the Difference between a Refugee and an Asylum Seeker? Retrieved from https://www.amnesty.org.au/refugee-andan-asylum-seeker-difference/

Anderson, S. (2020, August 20). A Review of Trump Immigration Policy. Retrieved from

https://www.forbes.com/sites/stuartanders on/2020/08/26/fact-check-and-review-oftrump-immigrationpolicy/\#52c95d7b56c0

Anghie, A. (2004). Imperialism, Sovereignty and the Making of International Law. New York: Cambridge University Press.

Dolmage, J. T. (2018). Disabled Upon Arrival: Eugenics, Immigration, and the Construction of Race and Disability. The Ohio State UP.

FBI. (n.d.). What We Investigate. Retrieved from

https://www.fbi.gov/investigate/terrorism? _cf_chl_jschl_tk_=9ba7012176404742a 1eb82c78435de632dd91a82-16067320320 -

AYZ41Wfkn_A7aLeXpnKMmKfJqnMV uZwzJjAW8QUx3Rpx2iuBnGLmBLFqfi BIj7iJcE5JASsnobPdGzJNTGa39c_mFt4 yihIgwKM0N9jxuUvNhCQTZ7SChlrMc xU1lx2FaDrtj9uwYTM

Gilsinan, K. (2018, December 11). Trump Keeps Invoking Terrorism to Get His Border Wall. Retrieved from https://www.theatlantic.com/international/ archive/2018/12/trump-incorrectly-linksimmigration-terrorism/576358/

Glennon, B. (2020, July 2020). Why the Trump Administration's Anti-Immigration Policies are the United States' loss and the Rest of the World's Gain. Retrieved from https://www.brookings.edu/blog/upfront/2020/07/20/why-the-trumpadministrations-anti-immigration-policiesare-the-united-states-loss-and-the-rest-ofthe-worlds-gain/

Haddad, E. (2008). The Refugee in International Society, Between Sovereigns. New York: Cambridge University Press. 
History. (2019, May 14). U.S. Immigration Timeline. $\quad$ Retrieved from https://www.history.com/topics/immigrati on/immigration-united-states-timeline

Ibe, P. (2020, November 2). How Trump is Making It Harder for Asylum Seekers. Retrieved from https://www.afsc.org/blogs/news-andcommentary/how-trump-making-itharder-asylum-seekers

Janmyr, M. (2013). Protecting Civilians in Refugee Camps: Unable and Unwilling States, UNHCR and International Responsibility. Leiden; Boston: Martinus Nijhoff Publishers.

Klug, F. (2000). Values for a Godless Age: The History of the Human Rights Act and its Political. Penguin.

Library of Congress. (n.d.). Religion and the Founding of the American Republic. Retrieved from https://www.loc.gov/exhibits/religion/rel0 1.html

Library of Congress. (n.d.). U.S. History Primary Source Timeline. Retrieved from https://www.loc.gov/classroommaterials/united-states-history-primarysource-timeline/colonial-settlement-16001763/overview/

Mutua, M. (2001). "Savages, Victims, and Saviors: The Metaphor of Human Rights." Harvard International Law Journal, XLII(1), 201-245.

National Security \& Defense. (2017, March 6). Executive Order Protecting the Nation from Foreign Terrorist Entry into the United States. Retrieved from https://www.whitehouse.gov/presidentialactions/executive-order-protecting-nationforeign-terrorist-entry-united-states-2/

Ngai, M. M. (2007, July). "Nationalism, Immigration Control, and the Ethnoracial Remapping of America in the 1920s." OAH Magazine of History, 11-15.
ODIHR. (n.d.). Guidelines for Addressing the Threats and Challenges of "Foreign Terrorist Fighters" within a Human Rights Framework. Retrieved from https://www.osce.org/files/f/documents/4/ 7/393503_2.pdf

Pittaway, E., Bartolomei, L. A., Pittaway, E. E., \& Doney, G. (2018, June 26). "Freedom from Persecution or Continued Abuse? An Analysis of the Meaning of Rights in Refugee Communities." Journal of Human Rights Practice, 10, 248-267.

Singh, A. S. (2019). "Third World Approach to International Law." International Journal of Law, 01-06.

The Washington Post. (2001, September 20). Text: President Bush Addresses the Nation. Retrieved from https://www.washingtonpost.com/wpsrv/nation/specials/attacked/transcripts/bu shaddress_092001.html

Ueda, R. (2006). A Companion to American Immigration. (R. Ueda, Ed.) Malden; Oxford; Carlton: Blackwell Publishing.

UNHCR. (n.d.). Convention and Protocol Relating to the Status of Refugees. Retrieved from https://www.unhcr.org/3b66c2aa10.html

UNHCR. (n.d.). What is a Refugee? Retrieved from https://www.unhcr.org/what-is-arefugee.html

United Nations. (n.d.). Foreign terrorist fighters. Retrieved from https://www.un.org/sc/ctc/focusareas/foreign-terrorist-fighters/

United Nations. (n.d.). Repertory of Practice of United Nations Organs. Retrieved from https://legal.un.org/repertory/art51.shtml

UNODC. (n.d.). Foreign Terrorist Fighters, Manual for Judicial Training Institutes, South-Eastern Europe. Retrieved from https://www.unodc.org/documents/terroris $\mathrm{m} /$ Publications/FTF\%20manual/000_Final _Manual_English_Printed_Version__no_foreword.pdf 
USA for UNHCR. (n.d.). What is a Refugee? Retrieved from https://www.unrefugees.org/refugeefacts/what-is-a-refugee/

Williams, J. (2020, April 11). Trump Administration Using Pandemic to Deport 30,000 Refugees and Asylum Seekers to Mexico. Retrieved from https://www.wsws.org/en/articles/2020/04 /11/immi-a11.html

Xu, P., Garand, J. C., \& Zhu, L. (2016, June). "Imported Inequality? Immigration and Income Inequality in the American States." State Politics \& Policy Quarterly, 147-171. 